Article

\title{
The Effects of Rural and Urban Areas on Time Allocated to Self-Employment: Differences between Men and Women
}

\author{
Nicholas Litsardopoulos ${ }^{1, *(1)}$, George Saridakis ${ }^{2}$ and Chris Hand ${ }^{1}$ \\ 1 Kingston Business School, Kingston University London, Kingston Hill KT2 7LB, UK; c.hand@kingston.ac.uk \\ 2 Kent Business School, University of Kent, Canterbury CT2 7FS, UK; g.saridakis@kent.ac.uk \\ * Correspondence: n.litsardopoulos@kingston.ac.uk
}

Received: 30 July 2020; Accepted: 21 August 2020; Published: 29 August 2020

check for updates

\begin{abstract}
This study investigates the association of the rural-urban divide and the time individuals allocate to self-employment. The empirical analysis uses fixed effects modelling on data from the UK Household Longitudinal Survey over the period 2009-2019. The study identifies significant differences in the time men and women allocate to self-employment between rural and urban areas according to their career age group. While men and women tend to allocate more time to self-employment in their senior career age when residents of urban areas, the time they allocate to self-employment between rural and urban areas in early- and mid-career age differs markedly. More importantly, we find that significant differences exist not only between residents of rural and urban areas, but also between residents of these areas and in-migrants to these areas. We find a significant positive effect on the time senior career age women who migrate to rural areas allocate to self-employment. In contrast, we find that early career men who move from rural to urban areas allocate significantly more time to self-employment. The results reveal the existence of complex dynamics between gender and age, which affect the allocation of time to self-employment between rural and urban areas.
\end{abstract}

Keywords: time in self-employment; gender; regional development; rural and urban areas; age; UK

\section{Introduction}

The development of the modern city as a centre for work has transformed the landscape of business opportunities for both the wage- and the self-employed [1-3]. The process of urbanism is strongly associated with economic growth that often dictates what the economy will produce, how will it produce, where will it produce, and for whom $[4,5]$. The study of urbanism and how the city has become a focus for socioeconomic pursuit dates to Wirth's 1938 publication of "Urbanism as a way of life" [6]. The city has become an engine of economic growth, and the location where venture capitalists and firms cluster [4]. A 2011 McKinsey report indicates that the top 600 urban centres (ranked by GDP) generate half the world's GDP [2]. Evidence from the United States suggests that venture capital-backed start-ups in digital industries are highly concentrated in dense urban areas (e.g., Lower Manhattan and downtown San Francisco) [3]. However, urbanisation and the idea of the city as an economic growth centre has also received criticism over the years [7-10]. A recent study by the Massachusetts Institute of Technology (MIT) Task Force on the Work of the Future explores the occupational changes in urban employment and incomes for the period 1980-2020, indicating that middle income jobs are fast disappearing from thriving cities such as New York and San Francisco [10]. The study shows that whereas the socioeconomic status of highly educated workers has improved during the past decade, that of non-highly educated workers has deteriorated.

The fast growth of urban economies has resulted in a continuous movement of young and well-educated people from rural areas to large cities [10-12]. In the UK, the Greater London area 
accounts for almost a third of the economy in England and Wales [13]. Such vibrant local economies are attractive for start-ups and offer greater opportunities for entrepreneurs. Moreover, major urban areas, such as London, account for the largest share of start-ups and creation of jobs, as well as a large share of the national economy $[2,13,14]$. However, with start-up costs being much higher in major cities (i.e., office, storage, personnel, etc.), it will be harder to break even in an urban area than a rural area, and failure will be considerably more costly. Most start-ups will not survive beyond their fifth year in business, while many do not survive even their first year [15-17]. Moreover, the hazard rate is likely higher in urban than rural areas [18]. Wirth argues that "On the whole, the city discourages an economic life in which the individual in time of crisis has a basis of subsistence to fall back upon, and it discourages self-employment" [6] (pp. 21-22). He explains that this is because while income is on average higher in the city than in the countryside, homeownership is rare and housing accommodation expenses are higher in the cities, absorbing as a result a large share of the earned income. Moreover, the rising cost of urban living (e.g., housing) has eroded the real earnings of city workers, pushing many workers away from major cities [10].

Urban areas offer a larger variety of jobs and possibilities for higher gross earnings compared to rural areas [14], which attracts large numbers of individuals from rural areas to major cities in pursuit of better employment opportunities and higher incomes. However, an increasing number of people also move out of major cities and into rural areas [14,19]. Urban areas offer several advantages in terms of access to goods and services compared to rural areas, but the greater noise and air pollution of urban areas, as well as the higher cost of living, can have a negative effect on individual life satisfaction and overall quality of life $[5,20,21]$. During the years leading to the 2008 financial crisis, there was an increase in the movement of people from urban to rural areas in the UK, which also continued during the recovery years [22,23]. While it is not uncommon for people to move out of major cities when jobs become scarce during financial downturns, data analysed by Champion [24] for the UK Government's Foresight Future of Cities Project indicate that the 2008 financial crisis had a profound impact on within-UK migration patterns, with no recovery of urban migration rates having been observed by 2011.

People who move to rural areas will often commute to cities in close proximity for work [25], which suggests the reason for moving to a rural area was not primarily for employment reasons. Nevertheless, people who move to rural areas might also seek to become self-employed [26]. A study on college graduates in the United States found that graduates who were residents of rural areas were more likely to be self-employed rather than wage-employees compared to the graduates residents of urban areas [27]. Several differences between urban and rural areas, such as differences in life satisfaction and the likelihood of self-employment, have already been investigated. In this paper, we argue that self-employment can offer a sustainable source of income to individuals in rural areas and the means to promoting sustainable regional economic development. However, it is unclear if individuals switch their employment when they move from a rural to an urban area (and vice versa) or if they continue their previous wage- or self-employment at the new location. Additionally, while there is research on the different drivers of self-employment for men and women [28-30], less is known about whether the effect of location on self-employment is the same for men and women, or if there are differences.

To answer these questions, our research uses data from the UK Household Longitudinal Survey (UKHLS) over the period 2009-2019. We employ fixed effect modelling to control for unobserved heterogeneity and examine subsamples of men and women. Since time-invariant variables are automatically omitted in the fixed effects model, any changes in the response variable must be due to variation in other than the fixed characteristics [31-33]. The rich data of UKHLS allow us to capture the effect of the rural-urban divide, while controlling for individual characteristics, such as educational achievement and socioeconomic class.

The paper follows the following structure. Section 2 reviews the literature and derives the hypotheses to be tested. Section 3 describes the data used in this paper and the empirical model. 
Section 4 presents the empirical results and discussion. Section 5 offers a discussion of the results and directions for future research. Lastly, Section 6 concludes the paper.

\section{Literature Review}

Urban districts account for 86 percent of the business economy in England and Wales, and for 78 percent in Scotland [13]. The world's top 10 leading areas of venture capital investment are major cities that in 2010, accounted for 52 percent of the world venture capital investment, but just 1.4 percent of world's population [3]. Major cities such as San Francisco, New York, and London act as clusters of entrepreneurship, which attract a large share of venture capital investment. London also accounted for approximately 20 percent of UK's highest growth firms over the period 2005-2008 [34], which, not surprisingly, was the largest share of high-growth companies among UK regions. However, Wales and Northern Ireland also had an above average share of high growth firms, even though they are much smaller and peripheral regional economies compared to London [34]. Additionally, accessible rural areas have a high gross value added per worker, which is second only to that of major urban areas [13]. This suggests that rural areas in the periphery can sustain healthy local economies. Furthermore, the growing interest in rural areas is revealed in the statistics of newly constructed building prices. That is, villages, hamlets, and small towns that are identified as rural areas have seen a greater overall price growth of new dwellings compared to major cities [35]. While the overall rural population of England decreased by 0.2 percent over the period of 2011 to 2018, the population of Lower Super Output Areas (LSOAs) increased by 4.4 percent (LSOAs have an average population of 1500 people or 650 households. The 'Rural population and migration: Mid-year population 2018' report, notes that analyses using LSOAs may slightly underestimate the rural population).

The de-urbanisation that took place during the 2008 financial crisis may have originally pushed people away from cities since they could not support the cost of living associated with major cities (e.g., cost of housing). However, Champion [24] suggests that those who moved out of major cities, such as London, did not return later when the economy picked up. Rural in-migrants may have found that self-employment in rural areas offered a sustainable solution to income and standards of living. Williams and Shepherd [36] find that in the aftermath of an extreme event in rural Australia, individuals created business ventures as a means to overcome adversity, which not only created value for the entrepreneurs themselves, but also for their local communities. Mayer, Habersetzer, and Meili [37] argue that rural entrepreneurs who maintain links with urban centres can use the advantages of both areas (e.g., local knowledge) to their benefit and contribute to local sustainable development. Nevertheless, it has been observed that people often turn to self-employment out of necessity during economic crises when there are no wage-based sources of income, but when the economy recovers, those necessity-entrepreneurs tend to return to wage-employment once more $[15,38,39]$. However, self-employment has been continuously rising in the UK, even after the economy recovered from the 2008 economic crisis $[22,23]$.

With the advancement of intercity connectivity (i.e., high-speed rail, highways, etc.) and the increasingly reduced costs associated with the transportation of goods, logistics, and accounting, it would be plausible to assume that individuals who wish to pursue their entrepreneurial aspirations could do so without the need to live in a major city [26,37,40]. Evidence from the United States suggests that growth in rural self-employment is fostered by the relative proximity of rural areas to smaller metropolitan areas, but generally hampered by their proximity to larger metropolitan areas [41]. Rural areas in the UK have seen, in recent years, the restructuring of traditional rural industries and the development of local community enterprises, as well as rural small and medium enterprises (SMEs) [40,42]. Audretsch and Feldman [4] suggest that when start-ups are supported by networks, they enjoy a high degree of stability and also that cooperation of firms within a network can reduce the size-inherent disadvantages of small firms and so improve their viability. With the emergence of a myriad online platforms that connect businesses with other businesses and customers, 
the contemporary entrepreneur may have a new network available to them, which enables them to operate their business without being physically present in the city.

In a study of long distance commuting in rural England, Champion, Coombes, and Brown [25] find that almost 35 percent of rural residents travel to work at distances of less than $5 \mathrm{~km}$, another 17 percent travel to work at distances of at least $20 \mathrm{~km}$, while approximately 11 percent of rural residents work from home. They also find that approximately 20 percent of recent movers to rural areas commute at least $20 \mathrm{~km}$ for their work, compared with only 12 percent of longer-term rural residents. The study notes some differences between residents and recent movers, but it also reveals that a large share of rural area residents works locally. Champion, Coombes, and Brown [25] note that the rationale for local work using the limit of $5 \mathrm{~km}$, is because no settlement in rural England has a diameter larger than $5 \mathrm{~km}$. Moreover, the study indicates that the reason for moving into a rural area is not primarily to move closer to the workplace. This may have to do with decisions related to quality of life away from problems of atmospheric pollution, noise, and traffic congestion that are often associated with cities $[5,21,43]$. It may also relate to the inflated home prices in major cities that force people to move to rural areas where they may find more affordable accommodation [20,44]. Ryan-Collins' $[20,44]$ research on homeownership, housing rents, and the increased cost of living in a big city, argues that local authorities have gradually withdrawn from offering affordable housing in the UK that has resulted in inflated house prices, which in major cities (e.g., London, Manchester) can be over 7 times the median income. Stockdale's [43] findings support the argument of rural in-migration due to rising urban costs and pollution, indicating that 62 percent of in-migrants in rural England continue to commute to their workplace at distances greater than $20 \mathrm{~km}$ away (likely an urban centre) from their rural residence. These workers earn more than 25,000 GBP per annum, when 49 percent of those who work locally earn that income. The DEFRA [14] report also notes that people living in rural areas, but commute to work in urban areas, have seen a greater increase in median incomes compared to those who live and work in urban areas (i.e., 2.3 percent versus 1.4 percent, based on 2016-2017 median earnings). Nevertheless, it is still possible that at a later period, the rural area in-migrants may find wage-employment closer to home or start their own business locally [25].

The attractiveness of rural areas can also be seen in the higher reported life satisfaction of rural areas compared to urban areas [21]. Rural areas appear to attract professionals and individuals from managerial classes who seek to combine employment with higher quality-of-life and more affordable housing [43]. However, managerial experience has also been associated with the launch of new businesses [45], and evidence suggests that such individuals indeed start up new businesses in the rural areas they migrate to. For example, Findlay, Short, and Stockdale [46] find that only 7 percent of the people who had recently moved to a rural area of Scotland worked in the primary sector, with the majority of recent in-migrants being employed in the service sector. They also observe that many in-migrants, who are highly skilled professionals, either operate their own business or work as managers in other businesses. The presence of skilled professionals and other individuals from managerial classes in rural areas can act as a vehicle for knowledge transmission and spillovers from urban to rural areas [47], and also encourage the overall entrepreneurial activity of rural areas [4]. Rural in-migrants strengthen rural-urban links, which can contribute to the long-run sustainable economic development of rural areas [37].

Furthermore, a study of Scotland shows that 45 percent of in-migrants who establish a business within the rural area were employing others and had created on average 1.6 extra jobs [46]. Stockdale [43] also finds that self-employed in-migrants to rural areas bring their businesses with them, creating opportunities for local employment expansion. A common theme about the in-migrants that move to rural areas is that it was "part of their life goals in shifting to becoming self-employed" [43] (p. 125). In-migrants appear to bring with them elements from their urban life experience that not only diversify the rural economies but also affect conditions associated with the generation of employment [43,46]. The above findings suggest that the migration process actually creates jobs in rural areas and is a more complex phenomenon than a simple residential relocation of urban households [46]. Therefore, 
self-employment and rural economic development appear intertwined with the quality of life possible in rural areas [48].

It is reasonable to assume that not all self-employed in rural areas become self-employed due to pull factors such as opportunities for higher income [27], but many turn to self-employment due to push factors, including the lack of better alternatives in wage-employment $[49,50]$. However, it has also been suggested that rural areas attract individuals who were already self-employed [43]. Nevertheless, important differences may exist between residents of rural areas and in-migrants with regards to their allocation of time to self-employment. The number of registered businesses in rural areas is greater than in urban areas when accounting for their population [14], which suggests that rural-based businesses are smaller than urban-based ones. The DEFRA [14] report finds that the rural areas in England had 585 registered businesses per 10,000 population, when urban areas had 406. Nevertheless, businesses in urban areas of England employed approximately 28.9 million employees, compared to just above 3.5 million employees for the rural areas. Evidently, a large percentage of businesses in rural areas are businesses with only a few employees, or even self-employed professionals with no employees. There is also some evidence of a growing number of individuals living in rural areas who work from home [26]. Therefore, either due to pull or push factors, it is possible that individuals will tend to spend more time as self-employed rather than wage-employees in rural areas compared to urban areas.

Nevertheless, in-migrants of rural and urban areas might allocate differently their time to self-employment compared to those who reside in rural or urban areas [51]. The demographics of rural/urban areas suggest that individuals tend to live in major cities when younger and in rural areas when older. DEFRA [14] reports that approximately 55 percent of the individuals living in rural areas are aged above 45 years old compared to approximately 40 percent in urban areas. The self-employed tend to be in general older than wage-employees $[52,53]$. This is often associated with accumulation of experience and expertise that lead to specialisation and the ability to recognise entrepreneurial opportunities [52,54,55]. Hence, greater self-employment might be expected in rural areas based on the rural age profile. However, urban areas may offer better overall opportunities for either wage- or self-employment, depending on the career stage, age, and employment experience/expertise of individuals, due to greater business activity taking place in urban areas compared to rural areas $[13,14,56]$.

There is also some evidence of differences between men and women in terms of rural self-employment. Champion, Coombes, and Brown [25] find that men who migrate to rural areas are more likely to commute more than $20 \mathrm{~km}$ for work than women, suggesting that that men who migrate to rural areas tend to maintain their previous jobs in the city whilst women will tend to find employment closer to home. The authors suggest that women tend to work locally because of gender roles associated with caring for family and home. It could be argued though, that more experienced women who migrate to rural areas will be more likely to become self-employed than others. Based on their experience, they are better able to spot opportunities and respond to them.

The above literature leads us to form three hypotheses: $\mathrm{H} 1, \mathrm{H} 2 \alpha$, and $\mathrm{H} 2 \beta$. We express these hypotheses as:

H1: Individuals who live in rural areas will have spent more time in self-employment than individuals who live in urban areas.

$\mathbf{H} \mathbf{2} \alpha$ : Older men who migrate from urban areas to rural areas are less likely to have spent more time in self-employment.

H2ß: Older women who migrate from urban areas to rural areas are more likely to have spent more time in self-employment. 


\section{Materials and Methods}

\subsection{Data}

We used data from the UK Household Longitudinal Study (UKHLS), also known as the Understanding Society survey (for further information, see Knies, [57]). The Understanding Society survey is a well-established and widely used longitudinal dataset, based at the University of Essex and funded by the Economic and Social Research Council (ESRC). The Understanding Society survey collects data from every household member, aged 16 and above. The same household is surveyed in the same quarter each year, mainly from face-to-face interviews, with a small supplement of telephone interviews. Understanding Society covers approximately 40 thousand households (at wave 1). At the time of this study, there were data for nine waves publicly available. The analysis retained only the observation for participants who were either wage-employed or self-employed in waves 1-9, surveyed over the period 2009-2019. This way, we limited the effects from becoming self-employed out of necessity due to unemployment [58-60]. Any participants with missing values among the variables examined in the models were removed. The final sample contained 43,614 observations, of which 46.99 percent were men and 53.01 percent were women.

\subsection{Model Specification}

The data analysis used fixed effects (FE) modelling to examine the data, though a random effects (RE) model is also reported for comparative reasons. The FE estimator (also known as the within estimator) provides effect estimates of the time-varying factors. As such, the time-constant unobserved heterogeneity no longer presents a problem [31-33]. Formally, the FE model is expressed as:

$$
y_{i t}-\overline{y_{i}}=\beta\left(x_{i t}-\bar{x}\right)+e_{i t}-\bar{e}_{i}
$$

The dependent variable for time in self-employment (tSEMP) is constructed as the share of time spent in self-employment to total time in employment (either wage-employment or self-employment). Following the empirical entrepreneurship literature, self-employment can be used as a proxy for en-trepreneurship, since entrepreneurs are typically individuals who have started and developed their own business enterprises $[39,55,61,62]$. Nevertheless, we are aware of the issues arising from this approach and we discuss them in Section 5.2 Limitations and further research. tSEMP is a continuous variable that denotes the ratio of time in self-employment to total employment time. tSEMP ranges from 0 to 1 , where 0 indicates that no time at all was dedicated in self-employment and 1 indicates that all employment time was dedicated in self-employment. Using this approach to measure the employment experience of individuals offers a way to measure self-employment experience which captures the actual share of self-employment experi-ence at each wave. This way, the risk of recall bias occurring from asking respondents to recall infor-mation in retrospect is being limited [63-66]. The independent variable for Urban/Rural is derived from the Office for National Statistics Rural and Urban Classification of Output Areas 2001. The indicator assumes a value of (1) if the address falls within urban settlements with a population of 10,000 or more, or (0) otherwise. However, we expected the effect of residential location to differ for residents and for in-migrants. Following the definition of long-term migrant used by the UK Department for Environment, Food and Rural Affairs and the Of-fice for National Statistics, this study uses the term 'resident' for those who usually live in an area and have resided there for at least a year. To examine if and how residents and in-migrants differ, we first created two variables which captured, for those who moved, the time the respondents moved into a rural area or the time they moved into an urban area. We also created a variable which took the value of 1 if the respondent lived in an urban area throughout the period covered by our data. For movers, this was the period lived in an urban area after the urban migration took place. In our model, our reference category was rural area residence. This allowed us to capture the specific effect of rural and urban in-migration on the time spent in self-employment sepa-rately from the effect of 
rural and urban residence. We also created an age variable with three age groups, for early career age (up to 25 years of age), middle career age (over 25 and up to 45 years of age), and senior career age (over 45 years of age), using the age information from Department for Education [67] and DEFRA [14], which we used as a proxy for experience.

Other control variables included health status, part-time employment, education, marital status, the presence of children in the household and their age, and homeownership. Controls were also included for the five socioeconomic status categories (NS-SEC5), the industrial sector they were employed in, and the geographical region of the household. Following previous studies [68], homeownership was used as a proxy of individuals' financial standing as well as the combined gross personal monthly income from job/business, savings, and investments. 'Gross personal income' is by default calculated per month in the UKHLS, and therefore, it was transformed to per annum before it was combined with 'income from savings and investments' which is, by default, calculated per annum in the UKHLS. Table A1 in the Appendix A presents a descriptive summary of the variables used in the analysis.

\section{Results}

\subsection{Descriptive Statistics}

The majority of men and women are employed in salaried jobs, that is 82.22 percent of men and 91.05 percent of women, with a small share of them working as self-employed (i.e., 17.78 percent of men and 8.95 percent of women). In total, 76.79 percent of men and 74.79 percent of women are living in urban areas, whereas 23.21 percent of men and 25.21 percent of women are living in rural areas. The mean age of individuals living in rural areas is 47.1 years of age and 44.5 for those in urban areas (see the descriptive statistics in Table A1 in the Appendix A). In line with the literature, the age distribution indicates the expected negative skew for rural areas (see Table A2 in the Appendix A). Approximately 54.2 percent of the sample population living in rural areas are aged above 45 years, whereas the share of the sample population above the age of 45 is approximately 53.4 percent.

\subsection{Empirical Analysis}

The analysis offers some important insight in the effects of gender and age towards the time individuals spend in self-employment in urban and rural areas. Overall, the results indicate that age plays a dominant role in men's and women's allocation of time to self-employment. Table 1 presents the analysis results for the overall model and the separate model specifications for men and women.

Table 1. Rural-Urban areas and Time in Self-employment: Random and Fixed effects models.

\begin{tabular}{|c|c|c|c|c|}
\hline & RE Mix-Gender & FE Mix-Gender & FE Men & FE Women \\
\hline & I & II & III & IV \\
\hline Urban Area Residence & -0.003 & $0.006^{* *}$ & 0.005 & $0.006^{* *}$ \\
\hline Urban migration & $-0.013^{* * *}$ & -0.007 & -0.009 & -0.005 \\
\hline Rural migration & -0.001 & 0.003 & 0.000 & 0.005 \\
\hline \multicolumn{5}{|l|}{ (Baseline: Rural Area Residence) } \\
\hline Gender: woman & $-0.061^{* * *}$ & (omitted) & (omitted) & (omitted) \\
\hline \multicolumn{5}{|l|}{ Career Age group } \\
\hline Middle & $0.007^{* * *}$ & $0.007^{* * *}$ & 0.005 & $0.010^{* * *}$ \\
\hline Senior & $0.012^{* * *}$ & $0.010^{* * *}$ & 0.006 & $0.013^{* * *}$ \\
\hline \multicolumn{5}{|l|}{ (Baseline: Early career) } \\
\hline Health status & 0.000 & 0.000 & -0.001 & 0.000 \\
\hline Part-time work & $0.006^{* * *}$ & $0.004^{* * *}$ & $0.016^{* * *}$ & 0.001 \\
\hline \multicolumn{5}{|l|}{ Educational achievement } \\
\hline High School & $-0.014 *$ & 0.005 & 0.005 & 0.005 \\
\hline +16 Education & -0.005 & 0.004 & 0.011 & 0.000 \\
\hline University & -0.011 & -0.003 & -0.012 & 0.002 \\
\hline $\begin{array}{c}\text { Vocational Qualification } \\
\text { (Baseline: Elementary school) }\end{array}$ & -0.012 & -0.001 & 0.007 & -0.005 \\
\hline
\end{tabular}


Table 1. Cont.

\begin{tabular}{|c|c|c|c|c|}
\hline & RE Mix-Gender & FE Mix-Gender & FE Men & FE Women \\
\hline \multicolumn{5}{|l|}{ Marital status } \\
\hline Married/Civil Partner & $0.005^{* * *}$ & $0.005^{* * *}$ & $0.007^{* *}$ & 0.003 \\
\hline Divorced/Separated & $0.007^{* * *}$ & $0.006^{* *}$ & $0.008^{* *}$ & 0.003 \\
\hline Widowed & 0.002 & -0.001 & $-0.024^{* *}$ & 0.005 \\
\hline \multicolumn{5}{|l|}{ (Baseline: Single/never married) } \\
\hline \multicolumn{5}{|l|}{ Number of Children in $\mathrm{HH}$} \\
\hline Aged 0-4 & $-0.003^{* * *}$ & $-0.003^{* * *}$ & -0.002 & $-0.003^{* * *}$ \\
\hline Aged 5-11 & 0.000 & 0.001 & -0.002 & $0.004^{* * *}$ \\
\hline Aged 12-15 & 0.000 & 0.000 & -0.001 & 0.001 \\
\hline \multicolumn{5}{|l|}{ (Baseline: No children) } \\
\hline \multicolumn{5}{|l|}{ Socioeconomic class } \\
\hline Management and professional & $0.013^{* * *}$ & $0.012 * * *$ & $0.018^{* * *}$ & $0.008^{* * *}$ \\
\hline Intermediate & 0.003 & $0.003 *$ & 0.003 & 0.003 \\
\hline Small employer and own account & $0.349^{* * *}$ & $0.318^{* * *}$ & $0.328^{* * *}$ & $0.300 * * *$ \\
\hline Lower supervisory and technical & -0.001 & -0.001 & -0.003 & 0.003 \\
\hline (Baseline: Routine and Semi-routine) & & & & \\
\hline Income from job/business and investments & $0.000 * * *$ & $0.000 * * *$ & $0.000 * * *$ & 0.000 \\
\hline Homeownership & 0.001 & -0.001 & $-0.006^{*}$ & $0.003 *$ \\
\hline \multicolumn{5}{|l|}{ Industrial Sector } \\
\hline Agriculture, forestry, and fishing & $0.066^{* * *}$ & $0.026^{* *}$ & $0.054^{* * *}$ & -0.002 \\
\hline Mining and quarrying & -0.001 & 0.000 & 0.001 & (omitted) \\
\hline Manufacturing & $0.008^{* *}$ & 0.003 & 0.011 & 0.007 \\
\hline Electricity, gas, steam, and air conditioning & 0.009 & 0.009 & 0.015 & 0.004 \\
\hline $\begin{array}{c}\text { Water supply; sewerage, waste management, and } \\
\text { remediation activities }\end{array}$ & -0.005 & -0.009 & 0.011 & $-0.067^{* *}$ \\
\hline Construction & $0.053^{* * *}$ & $0.035^{* * *}$ & $0.058 * * *$ & 0.006 \\
\hline $\begin{array}{l}\text { Wholesale and retail trade; repair of motor } \\
\text { vehicles and motorcycles }\end{array}$ & $0.011^{* * *}$ & 0.004 & $0.022^{* * *}$ & $-0.007 *$ \\
\hline Transportation and storage & $0.023^{* * *}$ & $0.019^{* * *}$ & $0.034^{* * *}$ & $0.012 *$ \\
\hline Accommodation and food service activities & $0.022 * * *$ & $0.014^{* * *}$ & $0.033^{* * *}$ & 0.002 \\
\hline Information and communication & $0.021^{* * *}$ & $0.010 *$ & $0.020 * *$ & 0.009 \\
\hline Financial and insurance activities & 0.008 & 0.000 & $0.019 *$ & $-0.011 *$ \\
\hline Real estate activities & $0.041^{* * *}$ & $0.037^{* * *}$ & $0.041^{* * *}$ & $0.053^{* * *}$ \\
\hline Professional, scientific, and technical activities & $0.041^{* * *}$ & $0.029^{* * *}$ & $0.041^{* * *}$ & $0.023^{* * *}$ \\
\hline Administrative and support service activities & $0.026^{* * *}$ & $0.018^{* * *}$ & $0.040^{* * *}$ & 0.004 \\
\hline Education & $0.017^{* * *}$ & $0.011^{* * *}$ & $0.048^{* * *}$ & -0.005 \\
\hline Human health and social work activities & $0.006^{*}$ & 0.001 & $-0.031 * * *$ & 0.006 * \\
\hline Arts, entertainment, and recreation & $0.020^{* * *}$ & 0.001 & 0.017 & -0.003 \\
\hline Other service activities & $0.019^{* * *}$ & 0.005 & 0.002 & 0.006 \\
\hline Activities of households as employers & $0.040^{* * *}$ & $0.044^{* * *}$ & $0.061^{* *}$ & $0.040 * * *$ \\
\hline \multicolumn{5}{|l|}{ (Baseline: Public services) } \\
\hline \multicolumn{5}{|l|}{ Region } \\
\hline North East & -0.012 & $0.022 *$ & $0.037^{* *}$ & -0.002 \\
\hline North West & $-0.031^{* * *}$ & $-0.030^{* * *}$ & $-0.034^{* *}$ & -0.018 \\
\hline Yorkshire And The Humber & $-0.016^{* *}$ & 0.012 & $0.040^{* * *}$ & -0.013 \\
\hline East Midlands & 0.011 & $0.049^{* * *}$ & $0.062^{* * *}$ & $0.037^{* * *}$ \\
\hline West Midlands & $-0.019 * *$ & 0.009 & 0.004 & 0.009 \\
\hline East Of England & $-0.028 * * *$ & $-0.025^{* * *}$ & -0.016 & $-0.030^{* * *}$ \\
\hline South East & $-0.014^{* *}$ & $-0.022^{* * *}$ & $-0.038^{* *}$ & 0.000 \\
\hline South West & -0.002 & 0.004 & -0.005 & 0.016 \\
\hline Wales & $-0.025^{* *}$ & -0.014 & -0.002 & $-0.032 *$ \\
\hline Scotland & $-0.044^{* * *}$ & $-0.048^{* * *}$ & $-0.035^{*}$ & $-0.049 * * *$ \\
\hline \multicolumn{5}{|l|}{ (Baseline: London) } \\
\hline Constant & $0.114^{* * *}$ & $0.059 * * *$ & $0.092 * * *$ & $0.031^{* *}$ \\
\hline \multicolumn{5}{|l|}{ Statistics } \\
\hline$x^{2}$ & $22,982.890$ & & & \\
\hline $\mathrm{F}$ & & 365.760 & 176.490 & 210.150 \\
\hline R-sq: within & 0.365 & 0.367 & 0.372 & 0.375 \\
\hline R-sq: between & 0.623 & 0.498 & 0.585 & 0.418 \\
\hline R-sq: overall & 0.588 & 0.476 & 0.553 & 0.405 \\
\hline Corr(u_i, Xb) & 0 (assumed) & 0.452 & 0.534 & 0.367 \\
\hline $\mathrm{N}$ & 38385 & 38385 & 17460 & 20925 \\
\hline
\end{tabular}

Note: ${ }^{*} p<0.1 ;{ }^{* *} p<0.05 ;{ }^{* * *} p<0.01$; we also tested the models restricting the sample to the labour force using the latest information from Gov.uk on Working, jobs, and pensions. The results of the restricted models are consistent with the original results and the conclusions remain unchanged. 
The results in Table 1 for the RE model (Column I) show that urban area residence is not a significant explanatory variable of the time individuals allocate to self-employment. Urban migration, however, is a significant explanatory variable $(p<0.01)$. Urban migration has a significantly negative effect on the time individuals allocate to self-employment. This shows that compared to rural areas, individuals who migrate to urban areas spend, on average, less time in self-employment. The random effects model results include effects from time-invariant variables (e.g., gender) and any interaction effects correlated with it, which makes it difficult to gain further insights. Nevertheless, the negative effect is not unexpected considering that self-employment is a source of employment when the supply of salaried jobs is limited [69-71], and urban areas offer many more wage-employment opportunities compared to rural areas [2,14]. The FE model (Column II) suggests that urban area residence has a positive effect on the time individuals allocate to self-employment compared to rural area residence. However, the time-invariant control for gender is omitted, forcing other variables to absorb the gender effect, which likely is quite significant. A Hausman specification test (HT) comparing the RE and FE models (Columns I and II) indicates that the RE specification does not adequately model individual effects $\left(\chi^{2}=3843.32 ; p<0.001\right)$. Hence, the mixed results offer only limited support for Hypothesis 1 , that "Individuals who live in rural areas will spend more time in self-employment than individuals who live in urban areas".

To examine the effects further, we estimate the FE model separately for men and women and present them in Columns III and IV of Table 1. We find that the urban residence effect is positively associated with time in self-employment for women, whereas for men, the effect is non-significant (perhaps suggesting that the greater opportunities for self-employment are counterbalanced by the availability of paid employment opportunities). Additionally, neither urban migration, nor rural migration appear to affect the time men and women allocate to self-employment. Furthermore, as might be expected, both middle and senior career age groups have a positive effect on time in self-employment for women $(p<0.01)[55,72,73]$. However, age does not appear to have significant explanatory power for men.

To examine the effects further, we analyse the FE models of men and women and decompose the models by career age groups. The results overall indicate that there exist differences between in-migrants and residents of urban and rural areas. Table 2 presents the analysis results for the model specification separated by age group for men and women.

Table 2. Urban-Rural areas and Time in Self-Employment: Men and Women by Career Age group.

\begin{tabular}{|c|c|c|c|c|c|c|}
\hline & $\begin{array}{l}\text { Early Career } \\
\text { Men (FE) }\end{array}$ & $\begin{array}{l}\text { Middle Career } \\
\text { Men (FE) }\end{array}$ & $\begin{array}{l}\text { Senior Career } \\
\text { Men (FE) }\end{array}$ & $\begin{array}{l}\text { Early Career } \\
\text { Women (FE) }\end{array}$ & $\begin{array}{c}\text { Middle } \\
\text { Career } \\
\text { Women (FE) }\end{array}$ & $\begin{array}{c}\text { Senior } \\
\text { Career } \\
\text { Women (FE) }\end{array}$ \\
\hline & I & II & III & IV & $\mathrm{V}$ & VI \\
\hline $\begin{array}{l}\text { Urban Area } \\
\text { Residence }\end{array}$ & $0.058^{* * *}$ & -0.004 & $0.041^{* * *}$ & -0.0023 & $0.013^{* * *}$ & $0.018^{* * *}$ \\
\hline Urban migration & $0.037^{*}$ & 0.004 & $-0.028 * *$ & -0.002 & -0.006 & 0.003 \\
\hline $\begin{array}{l}\text { Rural migration } \\
\text { (Baseline: Rural } \\
\text { Area Residence) }\end{array}$ & 0.024 & 0.005 & 0.016 & -0.005 & 0.008 & $0.018 * *$ \\
\hline Age & -0.000 & 0.000 & $0.001^{* * *}$ & $0.001 * *$ & $0.001^{* * *}$ & 0.000 \\
\hline Health status & 0.003 & -0.002 & $0.002 *$ & -0.001 & 0.000 & 0.000 \\
\hline Part-time work & -0.002 & $0.019^{* * *}$ & 0.001 & -0.003 & $0.003 *$ & 0.000 \\
\hline Homeownership & 0.015 & $-0.009 * *$ & 0.011 & $-0.009 * * *$ & 0.004 * & $0.011^{* * *}$ \\
\hline Constant & -0.054 & $0.072 * *$ & $0.065^{*}$ & -0.002 & 0.001 & 0.027 \\
\hline \multicolumn{7}{|l|}{ Statistics } \\
\hline $\mathrm{F}$ & 22.710 & 87.030 & 82.630 & 65.880 & 105.300 & 84.040 \\
\hline R-sq: within & 0.748 & 0.381 & 0.358 & 0.878 & 0.395 & 0.313 \\
\hline R-sq: between & 0.298 & 0.654 & 0.471 & 0.756 & 0.277 & 0.488 \\
\hline R-sq: overall & 0.252 & 0.598 & 0.464 & 0.715 & 0.292 & 0.484 \\
\hline Corr $\left(u \_i, X b\right)$ & 0.127 & 0.591 & 0.418 & 0.172 & 0.182 & 0.491 \\
\hline $\mathrm{N}$ & 438 & 8345 & 8677 & 565 & 9747 & 10613 \\
\hline
\end{tabular}

Note: Other controls as in Table $1 ;{ }^{*} p<0.1 ;{ }^{* *} p<0.05 ;{ }^{* * *} p<0.01$; We also test the models excluding the Age variable, and the results are similar. 
The results indicate an overall greater allocation of time to self-employment for men and women who live in urban areas, particularly at older ages. This can be explained from the perspective of the greater business opportunity availability in urban areas, where individuals can utilise their accumulated employment experience, expertise, and wealth to start up their own business [54,55,73-75]. Nevertheless, there are several differences in the effect of urban and rural areas between men and women and across age groups.

The path men follow with regards to self-employment appears consistent with the self-employment and entrepreneurship literature. That is, urban area residence has a positive effect on the time younger and senior career age men allocate to self-employment. This is not surprising since cities offer young professionals entrepreneurship opportunities that may be limited in rural areas $[2,14]$, allowing younger individuals to make career choices that often involve self-employment [55,76]. Additionally, older individuals also tend to turn to self-employment and start their own businesses after accumulating sufficient professional experience to make the transition [39,52,53,55]. Urban in-migrants also appear to allocate more time to self-employment rather than seek wage-employment when younger. Contrarily, urban in-migrant men in senior career ages allocate significantly less time to self-employment $(p<0.05)$.

Additionally, the linear age control for senior career men is also positively associated with time in self-employment $(p<0.01)$, offering further support that as men get older, they tend to allocate more time to self-employment. However, the results also show a difference between residents of urban areas and urban in-migrants. Specifically, senior age men who are in-migrants to urban areas spend significantly less time in self-employment, perhaps suggesting that much of the migration to urban areas is linked to wage-employment opportunities. Moreover, rural versus urban location does not appear to have a significant effect on the allocation of time to self-employment for middle career age men, which might indicate contrasting themes arising within this particular age group of men. The non-significant effects might be an indication that middle career age men have contrasting behaviours that cancel out each other. It is worth observing that the constant is also significant at $p<0.05$ in this specification. Overall, the results do not indicate that men alter their allocation of time between wage- and self-employment due to migration in a rural or an urban area. Hence, we do not find support for Hypothesis $2 \alpha$ that "Older men who migrate from urban areas to rural areas are less likely to spend more time in self-employment".

Women who are urban area residents allocate more time to self-employment compared to women in rural areas when in middle or senior career ages. When younger, the urban versus rural location does not significantly affect the time women allocate to self-employment. However, the linear age variable in this group has a significant positive effect on the time spent in self-employment; something we did not observe for men. Women, similarly to men, tend to allocate more time to self-employment as they get older, but at the same time, the impact of age has a stronger effect at a comparatively earlier stage in life for women than men. Often, women use self-employment to balance work and family $[73,77,78]$, which, combined with the business opportunities available in urban areas, might explain the positive effect of urban residence for mid-career ages. Furthermore, rural migration has a significant positive effect on time in self-employment for senior career age women. This is also something we did not observe for men. This is supportive of the literature that suggests women who move to rural areas tend to find employment closer to home [25], which suggests they are more likely to turn to self-employment. The results offer support for Hypothesis $2 \beta$ that "Older women who migrate from urban areas to rural are more likely to spend more time in self-employment".

Moreover, some of the control variables also offer interesting insights considering the effects of the rural-urban divide and the effect of age we have analysed so far. Specifically, part-time employment has a significant and positive association with time in self-employment for both men and women in the middle career age groups ( $p<0.01$ and $p<0.05$, respectively). Since this age group is typically when families are likely to be formed, the dual demands for work and family balance might influence the decision to turn to part-time employment [76,79-81]. The significant influence of part-time employment in this group might also be linked to the general rise in part-time self-employment in the aftermath of 
the 2008 economic crisis [22,82]. Health is also interesting, since it has a significant and positive effect only for men in the senior career age. Not surprisingly, this offers support for previous findings that older men choose self-employment for retirement reasons [72,76].

\section{Discussion}

\subsection{Summary}

This study examined the effects that living in a rural or urban area have on the time people allocate to self-employment. The empirical analysis used fixed effects modelling on rich panel data from the UKHLS over the period 2009-2019. The fixed effects model allowed us to control for unobserved heterogeneity, while the rich survey data enabled us to control for several individual characteristics, such as educational achievement, socioeconomic class, industrial sector of employment, marital status, and number of children, among others. Departing from previous analyses that use the typical binary wage- or self-employment variables and examine the transition to self-employment as an end in itself, our approach perceives the transition, to and from self-employment, as part of a continuous employment experience. Using this novel approach to measuring the time people spend in wage- and self-employment, the analysis shows that there exist important differences not only between rural and urban areas, but also differences between men and women. The gender differences between the time spent in self-employment in rural and urban areas become more pronounced when examined using separate age groups. Generally, the effects of rural and urban migration, as well as rural and urban residence, appear gendered and age group-specific. Our findings contribute towards the theoretical and methodological approach of examining self-employment and the rural-urban divide, as well as policy implications for rural development.

In line with the self-employment and entrepreneurship literature $[2,39,52,53,76]$, we find that older individuals tend to veer towards self-employment as they get older. Urban areas are, in general, positively associated with time in self-employment across most age groups. This effect is likely associated with the greater business opportunities available in larger markets of cities, compared to the smaller markets of rural towns and villages [2,14]. Therefore, major cities in the UK evidently remain centres of entrepreneurial activity [1-3]. Urban residence is positively associated with the time young men and senior men allocate to self-employment. Migration to urban areas is also positively associated with time in self-employment for men. However, our results show that younger men differ from senior men in their motivation to enter self-employment. Younger men, who tend to be less risk averse than older men, are willing to try out several career options in their efforts to find a job that satisfies their needs, including self-employment [72,76]. It might also be the case that young career age men are not concerned with future family and parenting responsibilities, and therefore, are more prone to take risks [83]. Older men might turn to self-employment after having increased their financial and human capital from a career in wage-employment $[54,55,73,84]$. Nevertheless, our findings cast doubt that senior career age men who move to rural areas from urban areas turn to self-employment and set up local businesses, as conjectured by Champion, Coombes, and Brown [25]. If we extrapolate a bit further, the finding that senior career age men who move from rural to urban areas allocate significantly less time to self-employment (see Table 2, Column III), may suggest that these men had been pushed to self-employment when previously residing in rural areas.

Interestingly, young women living in urban areas do not appear to be as attracted into self-employment as young men do. While young women's age still has a positive effect on time in self-employment, neither their urban residence nor urban migration alter their allocation of time between wage- and self-employment. This could be associated with family and parenting obligations, which for women, typically comes at an earlier life-stage [56]. In relatively more gender-egalitarian societies, such as the UK, wage-employment may offer a level of security for working class young mothers, which may not be accessible in self-employment [56]. Instead, women allocate more time to self-employment at middle career ages and senior career ages. This difference in the self-employment 
attitudes of men and women at their early career age might be related to self-efficacy [85-87]. In this sense, younger women who live in urban areas might feel more uncertain than young men in choosing the riskier career path of self-employment. This changes quickly after they accumulate some employment experience [85,87], which might explain the significant and positive effect of urban area residence for women in their middle career age group. Nevertheless, this age group includes the age period when people tend to have children and from families (e.g., late 20 s to early $40 \mathrm{~s}$ ). Since women typically bear the greatest burden of family responsibilities, they will be more likely to turn to self-employment and part-time work to balance work and family $[56,88,89]$. The results show that for this group of women, urban residence and part-time employment are positively associated with time in self-employment. Therefore, the positive association may be associated more with work and family factors, rather than attitudinal choices to specific employment type [89-92]. However, urban migration is not, which indicates that women in mid-career ages who migrate to urban areas do not significantly change their allocation of time to self-employment.

When looking at the senior career women, the results show that both urban residence and rural migration positively affect the allocation of time to self-employment. Women in this age group who live in urban areas might turn to self-employment due to age effects associated with human and financial capital, similarly to women in the mid-career age group $[55,73,84]$. The age effect though might not be the only reason that rural in-migrant women turn to self-employment. It may be the case that they bring new ideas from their experience in the city and start up their business there. Considering that rural in-migrant women do not travel far from home to work [25], this suggests they work locally in the rural area they live. Given the limited wage-employment opportunities of rural areas [14], there might not find suitable jobs for these in-migrant women, hence, they choose to become self-employed. However, their past experience from working in urban areas might still facilitate their entrepreneurial aspiration, regardless of initial motives $[36,37,83]$.

\subsection{Limitations and Further Research}

Like any other study, our study has some limitations. In this analysis, we use self-employment as a proxy for entrepreneurship. While there are distinctions between the two concepts, there are also major overlapping themes between the two. For example, both entrepreneurs and self-employed are individuals who typically do not work for someone else's business but have started and developed their own business enterprises. In empirical studies that examine individual-level data and not firm-level data, and given the practical difficulties in identifying the entrepreneur, self-employment has been traditionally used as a proxy [93]. Another limitation is that our analysis does not directly control for opportunity or necessity entrepreneurship. Therefore, we cannot know with certainty if men and women were pulled or pushed into self-employment. However, as our sample was restricted to those continuously in wage- or self-employment, the results are more likely to capture the effects of pull rather than push factors. Investigating whether the urban or rural location impacts the emergence of necessity or opportunity entrepreneurial activity in each area would be a fruitful avenue for future research. Additionally, the UK is a developed country with mature welfare institutions, which further decreases the probability of entrepreneurial activity out of necessity [94]. Nevertheless, more research is needed to fully understand the push or pull factors of self-employment motivations of rural/urban residents and in-migrants. It must also be noted that regional heterogeneity can affect the differences between rural and urban areas, as it is evident from the results of the region control variable. These remain potentially important issues to address in future research on sustainable regional development.

\section{Conclusions}

The results show that there exist complex dynamics of gender and age, which affect the allocation of time to self-employment between rural and urban areas. Residents and in-migrants of rural/urban areas also exhibit differences in the time they allocate to self-employment based on their gender and career age group. The rural versus urban location appears to exert contrasting effects on men and 
women that need to be considered in entrepreneurship policy, as well as rural/urban development planning. Nevertheless, our findings show that overall, urban areas are positively associated with the time individuals allocate to self-employment and remain a magnet for young men with entrepreneurial intentions. These findings support those by Champion and Shepherd, [11] Dobbs et al., [2], ONS [13], and DEFRA [14]. Rural areas, on the contrary, are positively associated with the time senior career women allocate to self-employment, which may reveal links with age and social entrepreneurship [83]. However, limited internet connection and speed is still a factor that hinders rural entrepreneurship [95]. Improvements in communication and transportation infrastructure can minimise the distance between rural and urban areas, which allows entrepreneurs to conduct their business from rural areas without the need to live in a major city $[40,41]$. Self-employment might be driven by different reasons for young or senior men and women who live in rural or urban areas, but nevertheless, self-employment offers an opportunity to create jobs for the self-employed and others in the area they live [14,96].

Author Contributions: Formal analysis, N.L.; Investigation, N.L.; Methodology, N.L. and G.S.; Project administration, N.L.; Supervision, G.S. and C.H.; Writing—original draft, N.L.; Writing—review \& editing, N.L., G.S. and C.H. All authors have read and agreed to the published version of the manuscript.

Funding: This research received no external funding.

Conflicts of Interest: The authors declare no conflict of interest.

\section{Appendix A}

Table A1. Descriptive statistics.

\begin{tabular}{|c|c|c|c|c|}
\hline \multicolumn{5}{|c|}{ Summary Statistics } \\
\hline & \multicolumn{2}{|c|}{ Males } & \multicolumn{2}{|c|}{ Females } \\
\hline & Mean & Std. Dev. & Mean & Std. Dev. \\
\hline Self-Emp. dummy & 0.178 & - & 0.089 & - \\
\hline Wage-Emp. dummy & 0.822 & - & 0.911 & - \\
\hline Part-Time Employment & 0.074 & - & 0.352 & - \\
\hline Age & 45.152 & 10.581 & 45.120 & 10.234 \\
\hline Self-Employees Age & 49.846 & 10.679 & 48.771 & 10.800 \\
\hline Wage-Employees Age & 44.137 & 10.282 & 44.761 & 10.106 \\
\hline Homeownership & 0.838 & - & 0.823 & - \\
\hline Urban Area Residence & 0.768 & - & 0.748 & - \\
\hline Health status & 3.671 & 0.920 & 3.660 & 0.938 \\
\hline $\begin{array}{c}\text { Income from job/business and investments } \\
\text { Marital status }\end{array}$ & $37,296.640$ & $26,102.990$ & $25,636.310$ & $18,212.790$ \\
\hline Single/Never Married & 0.216 & - & 0.215 & - \\
\hline Married/Civil Partner & 0.682 & - & 0.611 & - \\
\hline Divorced/Separated & 0.095 & - & 0.155 & - \\
\hline Widowed & 0.006 & - & 0.019 & - \\
\hline \multicolumn{5}{|l|}{ Number of Children in $\mathrm{HH}$} \\
\hline Aged $0-4$ & 0.201 & - & 0.157 & - \\
\hline Aged 5-11 & 0.335 & - & 0.307 & - \\
\hline Aged 12-15 & 0.175 & - & 0.195 & - \\
\hline \multicolumn{5}{|l|}{ Educational achievement } \\
\hline Elementary Education & 0.094 & - & 0.081 & - \\
\hline High School & 0.315 & - & 0.295 & - \\
\hline +16 Education & 0.115 & - & 0.097 & - \\
\hline University & 0.384 & - & 0.377 & - \\
\hline Vocational Qualification & 0.091 & - & 0.150 & - \\
\hline \multicolumn{5}{|l|}{ Socioeconomic class } \\
\hline Management and professional & 0.512 & - & 0.500 & - \\
\hline Intermediate & 0.100 & - & 0.176 & - \\
\hline Small employer and own account & 0.127 & - & 0.063 & - \\
\hline Lower supervisory and technical & 0.089 & - & 0.044 & - \\
\hline Routine and Semi-routine & 0.172 & - & 0.217 & - \\
\hline
\end{tabular}


Table A1. Cont.

\begin{tabular}{|c|c|c|c|c|}
\hline \multicolumn{5}{|c|}{ Summary Statistics } \\
\hline & \multicolumn{2}{|c|}{ Males } & \multicolumn{2}{|c|}{ Females } \\
\hline & & & & \\
\hline Agriculture, forestry, and fishing & 0.010 & - & 0.005 & - \\
\hline Mining and quarrying & 0.003 & - & 0.001 & - \\
\hline Manufacturing & 0.156 & - & 0.049 & - \\
\hline Electricity, gas, steam, and air conditioning & 0.008 & - & 0.004 & - \\
\hline $\begin{array}{c}\text { Water supply; sewerage, waste management, and } \\
\text { remediation activities }\end{array}$ & 0.007 & - & 0.003 & - \\
\hline Construction & 0.095 & - & 0.012 & - \\
\hline $\begin{array}{l}\text { Wholesale and retail trade; repair of motor } \\
\text { vehicles and motorcycles }\end{array}$ & 0.106 & - & 0.128 & - \\
\hline Transportation and storage & 0.073 & - & 0.020 & - \\
\hline Accommodation and food service activities & 0.017 & - & 0.025 & - \\
\hline Information and communication & 0.073 & - & 0.016 & - \\
\hline Financial and insurance activities & 0.041 & - & 0.033 & - \\
\hline Real estate activities & 0.012 & - & 0.009 & - \\
\hline Professional, scientific, and technical activities & 0.075 & - & 0.062 & - \\
\hline Administrative and support service activities & 0.046 & - & 0.033 & - \\
\hline $\begin{array}{l}\text { Public administration and defence; compulsory } \\
\text { social security }\end{array}$ & 0.087 & - & 0.086 & - \\
\hline Education & 0.087 & - & 0.187 & - \\
\hline Human health and social work activities & 0.069 & - & 0.271 & - \\
\hline Arts, entertainment, and recreation & 0.015 & - & 0.020 & - \\
\hline Other service activities & 0.017 & - & 0.034 & - \\
\hline Activities of households as employers & 0.001 & - & 0.002 & - \\
\hline $\begin{array}{c}\text { Activities of extraterritorial organisations } \\
\text { Region }\end{array}$ & 0.000 & - & 0.000 & - \\
\hline North East & 0.043 & - & 0.047 & - \\
\hline North West & 0.110 & - & 0.108 & - \\
\hline Yorkshire And The Humber & 0.076 & - & 0.077 & - \\
\hline East Midlands & 0.082 & - & 0.089 & - \\
\hline West Midlands & 0.088 & - & 0.091 & - \\
\hline East Of England & 0.102 & - & 0.100 & - \\
\hline London & 0.101 & - & 0.082 & - \\
\hline South East & 0.145 & - & 0.133 & - \\
\hline South West & 0.109 & - & 0.111 & - \\
\hline Wales & 0.038 & - & 0.043 & - \\
\hline Scotland & 0.071 & - & 0.083 & - \\
\hline Northern Ireland & 0.034 & - & 0.038 & - \\
\hline Total Observation & 17,460 & & 20,925 & \\
\hline
\end{tabular}

Table A2. Age in Rural/Urban Areas: Skewness and Kurtosis.

\begin{tabular}{ccc}
\hline Age & Rural Area & Urban Areas \\
\hline Mean & 47.082 & 44.509 \\
\hline Skewness & -0.092 & -0.027 \\
\hline Kurtosis & 2.708 & 2.538 \\
\hline Pr(Skewness) & Skewness/Kurtosis tests for Normality (95 Cl) & \\
\hline Pr(Kurtosis) & 0.000 & 0.060 \\
\hline Adj chi2(2) & 0.000 & 0.000 \\
\hline Prob $>$ chi2 & 51.980 & - \\
\hline Observations & 0.000 & 0.000 \\
\hline
\end{tabular}




\section{References}

1. Feldman, M.P.; Audretsch, D.B. Location, Location, Location: The Geography of Innovation and Knowledge Spillovers; FS IV 96-28; WZB: Berlin, Germany, 1996.

2. Dobbs, R.; Smit, S.; Remes, J.; Manyika, J.; Roxburgh, C.; Restrepo, A. Urban World: Mapping the Economic Power of Cities; McKinsey Global Institute: San Francisco, CA, USA, 2001; Volume 62.

3. Adler, P.; Florida, R.; King, K.; Mellander, C. The city and high-tech startups: The spatial organization of Schumpeterian entrepreneurship. Cities 2019, 87, 121-130. [CrossRef]

4. Audretsch, D.B.; Feldman, M.P. Knowledge spillovers and the geography of innovation. In Handbook of Regional and Urban Economics; Henderson, V., Thisse, J.-F., Eds.; Elsevier: Amsterdam, The Netherlands, 2004; pp. 2713-2739. [CrossRef]

5. Knox, P.; Pinch, S. Urban Social Geography: An Introduction; Routledge: London, UK, 2014.

6. Wirth, L. Urbanism as a way of life. Am. J. Sociol. 1938, 44, 25-48. [CrossRef]

7. Molotch, H. The City as a Growth Machine: Toward a Political Economy of Place. Am. J. Sociol. 1976, 82, 309-332. [CrossRef]

8. Davis, M. Planet of Slums; Verso: New York, NY, USA, 2006.

9. Côté, J.E.; Levine, C.G. Identity, Formation, Agency, and Culture: A Social Psychological Synthesis; Psychology Press: London, UK, 2014.

10. Autor, D. The Faltering Escalator of Urban Opportunity The Faltering Escalator of Urban; MIT: Cambridge, MA, USA, 2020.

11. Champion, T.; Shepherd, J. Demographic change in rural England. In The Ageing Countryside: The Growing Older Population of Rural England; Age Concern Books: London, UK, 2006; pp. 29-50.

12. Public Health England. Health and Wellbeing in Rural Areas; Public Health England: London, UK, 2017.

13. ONS. Exploring Labour Productivity in Rural and Urban Areas in Great Britain: 2014; Office for National Statistic: Newport, UK, 2017.

14. DEFRA. Statistical Digest of Rural England 2019; Department for Environment, Food and Rural Affairs: London, UK, 2019.

15. Taylor, M.P. Survival of the Fittest? An Analysis of Self-Employment Duration in Britain. Econ. J. 1999, 109, 140-155. [CrossRef]

16. Saridakis, G.; Mole, K.; Storey, D.J. New small firm survival in England. Empirica 2008, 35, 25-39. [CrossRef]

17. Coad, A.; Frankish, J.; Roberts, R.G.; Storey, D.J. Growth paths and survival chances: An application of Gambler's Ruin theory. J. Bus. Ventur. 2013, 28, 615-632. [CrossRef]

18. Fritsch, M.; Brixy, U.; Falck, O. The Effect of Industry, Region, and Time on New Business Survival-A Multi-Dimensional Analysis. Rev. Ind. Organ. 2006, 28, 285-306. [CrossRef]

19. Saridakis, G.; Mendoza González, M.A.; Hand, C.; Muñoz Torres, R.I. Do regional self-employment rates converge in the UK? Empirical evidence using club-clustering algorithm. Ann. Reg. Sci. 2020, 65, 179-192. [CrossRef]

20. Ryan-Collins, J. Rethinking the Economics of Land and Housing, 1st ed.; Lloyd, T., MacFarlane, L., Eds.; Zed Books: London, UK, 2017.

21. Hand, C. Spatial influences on domains of life satisfaction in the UK. Reg. Stud. 2019, 54, 802-813. [CrossRef]

22. Wales, P.; Agyiri, A. Trends in Self-Employment in the UK: 2001 to 2015; ONS: London, UK, 2016.

23. ONS. A01: Summary of Labour Market Statistics; Office for National Statistics: Newport, UK, 2018.

24. Champion, T. People in Cities: The Numbers; Future of Cities, University of Newcastle: Callaghan, Australia, 2014.

25. Champion, T.; Coombes, M.; Brown, D.L. Migration and longer-distance commuting inac raaural England. Reg. Stud. 2009, 43, 1245-1259. [CrossRef]

26. Lowe, P.; Ward, N. Sustainable rural economies: Some lessons from the english experience. Sustain. Dev. 2007, 15, 307-317. [CrossRef]

27. Yu, L.; Artz, G.M. Does rural entrepreneurship pay? Small Bus. Econ. 2019, 53, 647-668. [CrossRef]

28. Clark, A.E. Job satisfaction and gender: Why are women so happy at work? Lab. Econ. 1997, 4, 341-372. [CrossRef]

29. Mallon, M.; Cohen, L. Time for a change? Women's accounts of the move from organizational careers to self-employment. Br. J. Manag. 2001, 12, 217-230. [CrossRef] 
30. Bender, K.A.; Donohue, S.M.; Heywood, J.S. Job satisfaction and gender segregation. Oxf. Econ. Pap.-New Ser. 2005, 57, 479-496. [CrossRef]

31. Mátyás, L.; Sevestre, P. (Eds.) The Econometrics of Panel Data: Fundamentals and Recent Developments in Theory and Practice; Advanced Studies in Theoretical and Applied Econometrics; Springer: Berlin/Heidelberg, Germany, 2008; Volume 46. [CrossRef]

32. Wooldridge, J.M. Econometric Analysis of Cross Section and Panel Data; MIT Press: London, UK, 2010.

33. Andreß, H.-J.; Golsch, K.; Schmidt, A.W. Applied Panel Data Analysis for Economic and Social Surveys; Springer Science \& Business Media: London, UK, 2013.

34. Anyadike-Danes, M.; Bonner, K.; Hart, M.; Mason, C. Measuring Business Growth: High-Growth Irms and Their Contribution to Employment in the UK; MBG/35; NESTA: London, UK, 2009. [CrossRef]

35. ONS. Property Sales in Rural and Urban Areas of England and Wales: September 2011 to Year Ending September 2015; ONS: Newport, UK, 2016.

36. Williams, T.A.; Shepherd, D.A. Victim entrepreneurs doing well by doing good: Venture creation and well-being in the aftermath of a resource shock. J. Bus. Ventur. 2016, 31, 365-387. [CrossRef]

37. Mayer, H.; Habersetzer, A.; Meili, R. Rural-Urban Linkages and Sustainable Regional Development: The Role of Entrepreneurs in Linking Peripheries and Centers. Sustainability 2016, 8, 745. [CrossRef]

38. Frankish, J.S.; Roberts, R.G.; Coad, A.; Storey, D.J. Is Entrepreneurship a Route Out of Deprivation? Reg. Stud. 2014, 48, 1090-1107. [CrossRef]

39. Saridakis, G.; Marlow, S.; Storey, D.J. Do different factors explain male and female self-employment rates? J. Bus. Ventur. 2014, 29, 345-362. [CrossRef]

40. Mahroum, S.; Atterton, J.; Ward, N.; Williams, A.M.; Naylor, R.; Hindle, R.; Rowe, F. Rural Innovation; IGI Global: London, UK, 2007. [CrossRef]

41. Tsvetkova, A.; Partridge, M.; Betz, M. Entrepreneurial and Employment Responses to Economic Conditions across the Rural-Urban Continuum. Ann. Am. Acad. Polit. Soc. Sci. 2017, 672, 83-102. [CrossRef]

42. Ward, N.; Atterton, J.H.; Kim, T.-Y.; Lowe, P.D.; Phillipson, J.; Thompson, N. Universities, the Knowledge Economy and "Neo-Endogenous Rural Development"; CRE Discussion Paper; Newcastle University: Newcastle upon Tyne, UK, 2005.

43. Stockdale, A. In-Migration and Its Impacts on the Rural Economy. In The New Rural Economy: Change, Dynamism and Government Policy; Hill, B., Ed.; Institute for Economic Affairs: London, UK, 2005.

44. Ryan-Collins, J. Why Can't You Afford a Home? John Wiley \& Sons: Cambridge, UK, 2018.

45. Capelleras, J.-L.; Contin-Pilart, I.; Larraza-Kintana, M.; Martin-Sanchez, V. Population Density and Individual Human Capital Influences on Entrepreneurial Growth Aspirations. In Academy of Management Proceedings; Academy of Management: Briarcliff Manor, NY, USA, 2015; Volume 2015, p. 14319.

46. Findlay, A.M.; Short, D.; Stockdale, A. The labour-market impact of migration to rural areas. Appl. Geogr. 2000, 20, 333-348. [CrossRef]

47. Audretsch, D.B.; Thurik, R. Linking Entrepreneurship to Growth; OECD Publishing: Paris, France, $2001 ;$ p. 34. [CrossRef]

48. Abreu, M.; Oner, O.; Brouwer, A.; van Leeuwen, E. Well-being effects of self-employment: A spatial inquiry. J. Bus. Ventur. 2019, 34, 589-607. [CrossRef]

49. Schjoedt, L.; Shaver, K.G. Deciding on an entrepreneurial career: A test of the pull and push hypotheses using the panel study of entrepreneurial dynamics data. Entrep. Theory Pract. 2007, 31, 733-752. [CrossRef]

50. Faggio, G.; Silva, O. Self-employment and entrepreneurship in urban and rural labour markets. J. Urban Econ. 2014, 84, 67-85. [CrossRef]

51. Lowe, P.; Ward, N. England's Rural Futures: A Socio-Geographical Approach to Scenarios Analysis. Reg. Stud. 2009, 43, 1319-1332. [CrossRef]

52. Blanchflower, D.G.; Oswald, A.; Stutzer, A. Latent entrepreneurship across nations. Eur. Econ. Rev. 2001, 45, 680-691. [CrossRef]

53. Warr, P.; Inceoglu, I. Work Orientations, Well-Being and Job Content of Self-Employed and Employed Professionals. Work Employ. Soc. 2018, 32, 292-311. [CrossRef]

54. Smeaton, D. Self-Employed Workers: Calling the Shots or Hesitant Independents? A Consideration of the Trends. Work Employ. Soc. 2003, 17, 379-391. [CrossRef]

55. Henley, A. Entrepreneurial Aspiration and Transition into Self-Employment: Evidence from British Longitudinal Data. Entrep. Reg. Dev. 2007, 19, 253-280. [CrossRef] 
56. Cheraghi, M.; Adsbøll Wickstrøm, K.; Klyver, K. Life-Course and Entry to Entrepreneurship: Embedded in Gender and Gender-Egalitarianism. Entrep. Reg. Dev. 2019, 31, 242-258. [CrossRef]

57. Knies, G. Understanding Society: Waves 1-8, 2009-2017 and Harmonised British Household Panel Survey: Waves 1-18, 1991-2009, User Guide; The Institute for Social and Economic Research: Colchester, UK, 2018.

58. McMullen, J.S.; Bagby, D.R.; Palich, L.E. Economic Freedom and the Motivation to Engage in Entrepreneurial Action. Entrep. Theory Pract. 2008, 32, 875-895. [CrossRef]

59. Kautonen, T.; Palmroos, J. The Impact of a Necessity-Based Start-up on Subsequent Entrepreneurial Satisfaction. Int. Entrep. Manag. J. 2010, 6, 285-300. [CrossRef]

60. Millán, J.M.; Hessels, J.; Thurik, R.; Aguado, R. Determinants of Job Satisfaction: A European Comparison of Self-Employed and Paid Employees. Small Bus. Econ. 2013, 40, 651-670. [CrossRef]

61. Blanchflower, D.G.; Oswald, A.J. What Makes an Entrepreneur? J. Labor Econ. 1998, 16, 26-60. [CrossRef]

62. Román, C.; Congregado, E.; Millán, J.M. Start-up Incentives: Entrepreneurship Policy or Active Labour Market Programme? J. Bus. Ventur. 2013, 28, 151-175. [CrossRef]

63. Paull, G. Biases in the Reporting of Labour Market Dynamics; IFS Working Papers; 02/10; IFS: London, UK, 2002.

64. Winter, S.G. Mistaken Perceptions: Cases and Consequences. Br. J. Manag. 2003, 14, 39-44. [CrossRef]

65. Cassar, G.; Craig, J. An Investigation of Hindsight Bias in Nascent Venture Activity. J. Bus. Ventur. 2009, 24, 149-164. [CrossRef]

66. Manzoni, A. In and out of Employment: Effects in Panel and Life-History Data. Adv. Life Course Res. 2012, 17, 11-24. [CrossRef]

67. Department for Education. Post-16 Education: Highest Level of Achievement by Age 25 England; Department for Education: London, UK, 2018.

68. Lofstrom, M.; Bates, T.; Parker, S.C. Why Are Some People More Likely to Become Small-Businesses Owners than Others: Entrepreneurship Entry and Industry-Specific Barriers. J. Bus. Ventur. 2014, 29, 232-251. [CrossRef]

69. Earle, J.S.; Sakova, Z. Business Start-Ups or Disguised Unemployment? Evidence on the Character of Self-Employment from Transition Economies. Labour Econ. 2000, 7, 575-601. [CrossRef]

70. Svaleryd, H. Self-Employment and the Local Business Cycle. Small Bus. Econ. 2015, 44, 55-70. [CrossRef]

71. Bosma, N.; Sternberg, R. Entrepreneurship as an Urban Event? Empirical Evidence from European Cities. Entrep. Reg. Context 2019, 48, 78-95. [CrossRef]

72. Blanchflower, D.G.; Mayer, B.D. A Longitudinal Analysis of Young Entrepreneurs in Australia and in the United States; NBER Working Paper; 3746; NBER: Cambridge, MA, USA, 1991.

73. Burke, A.E.; FitzRoy, F.R.; Nolan, M.A. Self-Employment Wealth and Job Creation: The Roles of Gender, Non-Pecuniary Motivation and Entrepreneurial Ability. Small Bus. Econ. 2002, 19, 255-270. [CrossRef]

74. Clark, A.E.; Oswald, A.J. Satisfaction and Comparison Income. J. Public Econ. 1996, 61, 359-381. [CrossRef]

75. Nanda, R. Cost of External Finance and Selection into Entrepreneurship; HBS Working Paper 08-047; Harvard Business School: Boston, MA, USA, 2008.

76. Georgellis, Y.; Wall, H.J. Gender Differences in Self-Employment. Int. Rev. Appl. Econ. 2005, 19, 321-342. [CrossRef]

77. Still, L.V.; Timms, W. Women's Business: The Flexible Alternative Workstyle for Women. Women Manag. Rev. 2000, 15, 272-283. [CrossRef]

78. Craig, L.; Powell, A.; Cortis, N. Self-Employment, Work-Family Time and the Gender Division of Labour. Work Employ. Soc. 2012, 26, 716-734. [CrossRef]

79. Ajayi-Obe, O.; Parker, S.C. The Changing Nature of Work among the Self-Employed in the 1990s: Evidence from Britain. J. Lab. Res. 2005, 26, 501-517. [CrossRef]

80. Keizer, R.; Dykstra, P.A.; Poortman, A.-R. The Transition to Parenthood and Well-Being: The Impact of Partner Status and Work Hour Transitions. J. Fam. Psychol. 2010, 24, 429-438. [CrossRef]

81. Zou, M. Gender, Work Orientations and Job Satisfaction. Work Employ. Soc. 2015, 29, 3-22. [CrossRef]

82. ONS. Labour Market Overview, UK; ONS: Newport, UK, 2020.

83. Jayawarna, D.; Rouse, J.; Kitching, J. Entrepreneur Motivations and Life Course. Int. Small Bus. J. 2013, 31, 34-56. [CrossRef]

84. Clark, A.E.; Oswald, A.; Warr, P. Is Job Satisfaction U-Shaped in Age? J. Occup. Organ. Psychol. 1996, 69, 57-81. [CrossRef] 
85. Bandura, A. Exercise of Personal Agency through the Self-Efficacy Mechanism. In Self-Efficacy: Thought Control of Action; Schwarzer, R., Ed.; Hemisphere Publishing Corporation: Washington, DC, USA, 1992; pp. 3-38.

86. Bandura, A.; Barbaranelli, C.; Caprara, G.V.; Pastorelli, C. Self-Efficacy Beliefs as Shapers of Children's Aspirations and Career Trajectories. Child Dev. 2001, 72, 187-206. [CrossRef] [PubMed]

87. Wilson, F.; Kickul, J.; Marlino, D. Gender, Entrepreneurial Self-Efficacy, and Entrepreneurial Career Intentions: Implications for Entrepreneurship Education. Entrep. Theory Pract. 2007, 31, 387-406. [CrossRef]

88. Burton, M.D.; Sørensen, J.B.; Dobrev, S.D. A Careers Perspective on Entrepreneurship. Entrep. Theory Pract. 2016, 40, 237-247. [CrossRef]

89. Zhou, M. Motherhood, Employment, and the Dynamics of Women's Gender Attitudes. Gend. Soc. 2017, 31, 751-776. [CrossRef]

90. Goffee, R.; Scase, R. Women in Charge: The Experience of Female Entrepreneurs; Allen and Unwin Ltd.: London, UK, 1985.

91. Greene, F.J.; Han, L.; Marlow, S. Like Mother, Like Daughter? Analyzing Maternal Influences Upon Women's Entrepreneurial Propensity. Entrep. Theory Pract. 2013, 37, 687-711. [CrossRef]

92. Yu, W.H.; Kuo, J.C.L. The Motherhood Wage Penalty by Work Conditions: How Do Occupational Characteristics Hinder or Empower Mothers? Am. Sociol. Rev. 2017, 82, 744-769. [CrossRef]

93. Gartner, W.B.; Shane, S.A. Measuring Entrepreneurship over Time. J. Bus. Ventur. 1995, 10, $283-301$. [CrossRef]

94. Reynolds, P.D.; Hay, M.; Bygrave, W.D.; Camp, S.M.; Autio, E. Global Entrepreneuship Monitor Executive Report 2001; Global Entrepreneurship Monitor: London, UK, 2002.

95. Deane, J. Self-Employment Review: An Independent Report; Department for Business, Innovation and Skills: London, UK, 2016.

96. McCollum, D.; Liu, Y.; Findlay, A.; Feng, Z.; Nightingale, G. Determinants of Occupational Mobility: The Importance of Place of Work. Reg. Stud. 2018, 52, 1612-1623. [CrossRef]

(C) 2020 by the authors. Licensee MDPI, Basel, Switzerland. This article is an open access article distributed under the terms and conditions of the Creative Commons Attribution (CC BY) license (http://creativecommons.org/licenses/by/4.0/). 